\title{
ANALISIS POTENSI LIKUIFAKSI AKIBAT GEMPA BUMI MENGGUNAKAN METODE SPT (STANDAR PENETRATION TEST) DAN CPT (CONE PENETRATION TEST) DI KABUPATEN BANTUL, YOGYAKARTA
}

\author{
Tini* $^{1}$, Adrin Tohari ${ }^{2}$, Mimin Iryanti ${ }^{1}$ \\ ${ }^{1}$ Prodi Fisika, FPMIPA, Universitas Pendidikan Indonesia \\ Jl. Dr. Setiabudhi No. 229, Bandung dan 40154 \\ ${ }^{2}$ PPG-LIPI, Komplek LIPI, Jl. Sangkuriang, Bandung 40135, \\ *Penulis Penanggungjawab. Email : tinifisika@gmail.com
}

\begin{abstract}
ABSTRAK
Gempa bumi yang terjadi di daerah Bantul, Yogyakarta pada 27 Mei 2006 dengan magnitudo gempa bumi sebesar 6.3 SR dapat menyebabkan terjadinya bahaya likuifaksi yang dapat merusak bangunan khususnya di wilayah Bantul Yogyakarta. Investigasi geoteknik yang telah dilakukan di Bantul, Yogyakarta dapat memberikan gambaran lapisan tanah yang berpotensi terjadinya likuifaksi. Analisis potensi likuifaksi dilakukan berdasarkan data SPT (Standard Penetration Test) dan CPT (Cone Penetration Test) dengan percepatan maksimum tanah menurut Gutenberg Richter di daerah penelitian rata-rata bernilai sebesar 2.93 $\mathrm{m} / \mathrm{s}^{2}$ dan menurut Donovan sebesar $2.88 \mathrm{~m} / \mathrm{s}^{2}$. Hasil analisis penelitian menunjukan bahwa lapisan tanah yang berpotensi likuifaksi didominasi oleh jenis tanah pasir lanauan da lanau pasiran yang berada pada kedalaman $0.2-3 \mathrm{~m}, 0.4$ m, 2.4 m, 3.6 m, 7.6 - $7.8 \mathrm{~m}$ dan $8.2 \mathrm{~m}$. Pengaruh percepatan maksimum tanah menurut Gutenberg Richter lebih besar terhadap terjadinya likuifaksi daripada menurut Donovan. Perbandingan hasil analisis potensi likuifaksi antara data SPT (Standard Penetration Test ) dan CPT (Cone Penetration Test) pada daerah penelitian menunjukan adanya kesamaan potensi likuifaksi pada lapisan tanah dengan kedalaman yang sama diantaranya pada kedalaman $0.2 \mathrm{~m}-4 \mathrm{~m}$, dengan nilai Cyclic Strees Ratio (CSR) rata-rata sebesar 0.2, sedangkan berdasarkan nilai Cyclic Resistance Ratio (CRR) terdapat perbedaan nlai. Analisis berdasarkan data CPT lebih baik daripada data SPT karena data CPT lebih rapat daripada data SPT.
\end{abstract}

Kata kunci: Likuifaksi, percepatan maksimum gempa, SPT (Standar Penetration Test), CPT (Cone Penetration Test), Cyclic Stress Ratio (CSR), Cyclic Resistance Ratio (CRR). 


\begin{abstract}
The earthquake that occurred in Bantul, Yogyakarta on May 27, 2006 with the magnitudo of the earthquake of 6.3 SR can caused liquefaction hazard which could damage to teh building in the municipals of Bantul, Yogyakarta. Geotechnical investigation was carried in Bantul Yogyakarta, can give information about liquefaction hazard in soil layer. The liquefaction potential lanalysis was conducted using SPT and CPT methods, with Gutenberg-Richter's maximum ground acceleration is $2.93 \mathrm{~m} / \mathrm{s}^{2}$ and Donovan's maximum ground acceleration is $2.88 \mathrm{~m} / \mathrm{s}^{2}$. Result of liquefaction analysis indicate that the soil layer domination of silty sand dan sandy silt at the depth of $0.2-3 \mathrm{~m}, 3.6 \mathrm{~m}, 4 \mathrm{~m} 7.6-$ $7.8 \mathrm{~m}$ and $8.2 \mathrm{~m}$. Gutenberg-Richter's maximum ground acceleration having influential for liquefaction potential better than Donovan's maximum ground acceleration. Ratio result of liquefaction was conducted using SPT same as soil layer with CPT in resech location at the depth $0.2 \mathrm{~m}-4 \mathrm{~m}$, with value Cyclic Strees Ratio (CSR) is 0.2. Even value Cyclic Resistances Ratio (CSR) have different value. The liquefaction potential lanalysis was conducted using CPT method better than SPT methods.
\end{abstract}

Keywords: Liquefacton, maximum acceleration earthquake, SPT (Standard Penetration Test), CPT (Cone Penetration Test), Cyclic Stress Ratio (CSR), Cyclic Resistance Ratio (CRR).

\section{Pendahuluan}

Indonesia terletak antara pertemuan tiga lempeng kerak bumi yaitu lempeng Pasifik, Eurasia dan lempeng India Australia. Kepulauan Indonesia merupakan daerah yang berada pada pertemuan antara 2 jalur gempa utama yaitu jalur gempa Mediterania dan jalur gempa Sirkum Pasifik. Oleh karena itu, Indonesia memiliki potensi bencana gempa bumi. Salah satunya di kabupaten Bantul, Yogyakarta. Daerah ini berbatasan langsung dengan samudra Hindia yang merupakan daerah terdekat dengan zona subduksi lempeng IndoAustralia dan Eurasia. Gempa Bantul yang terjadi pada tanggal 27 Mei 2006 menyebabkan ribuan orang

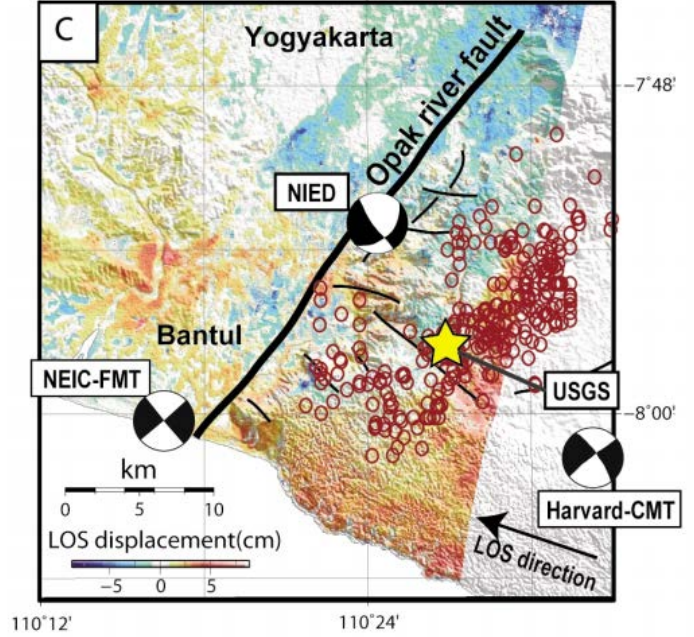

meninggal dunia dan mengalami luka parah dan bangunan-bangunan hancur rata dengan tanah. Gambar 1 yang merupakan peta sumber gempa di Bantul, Yogyakarta.

Gambar 1. Pusat gempa 27 Mei 2006 (USGS) 
Gempa bumi merupakan bencana alam yang terjadi dibawah permukaan tanah yang dapat menyebabkan terjadinya kerusakan pada struktur tanah. Kerusakan pada tanah ini diakibatkan oleh besarnya energy yang dilepaskan oleh pusat gempa (hypocenter) berupa getaran yang merambat dipermukaan bumi. Salah satu kerusakan pada struktur tanah akibat gempa bumi yaitu likuifasi.

Likuifaksi adalah suatu peristiwa perubahan fase padat menjadi fase cair yang disebabkan oleh peningkatan tekanan air pori dalam rongga tanah (Indris dan Boulanger, 2004). Dampak dari terjadinya peninggkatan tekanan air pori, tanah akan kehilangan kuat geser secara drastis akibat turunnya tegangan efektif air pori tanah (Indris dan Boulanger, 2008). Kejadian ini terutama berkaitan dengan kondisi tanah pasiran jenuh yang memiliki kepadatan lepas atau sedang.

Beberapa contoh dari peristiwa likuifaksi yang pernah terjadi di Indonesia yaitu kerusakan-kerusakan yang dihasilkan oleh gempa bumi di Bengkulu tahun 2000 dan 2007, gempa bumi Aceh tahun 2004, gempa bumi Nias tahun 2005, dan gempa bumi Yogyakarta tahun 2006 (Soebowo dkk., 2009). Gambar 2 merupakan salah satu likuifaksi akibat gempa bumi di kabupaten Bantul.

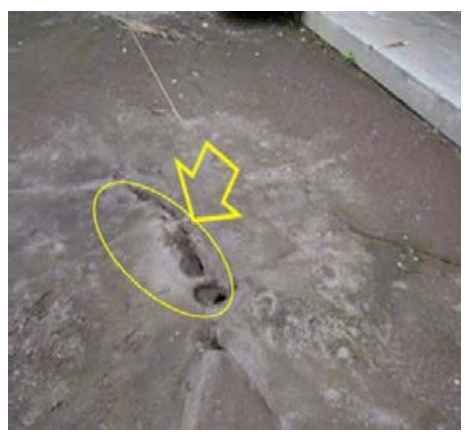

Gambar 2 Likuifaksi akibat gempa bumi di kabupaten Bantul, Yogyakarta (Siswosukarto, 2006)

Untuk mengetahui potensi bahaya likuifaksi di daerah tersebut, maka diperlukan analisis kondisi bawah permukaan tanah, agar dapat menjadi bahan pertimbangan untuk mengambil keputusan apakah daerah tersebut berbahaya atau aman bagi warga setempat. Analisis kondisi bawah permukaan untuk mengetahui potensi likuifaksi akibat gempa bumi di daerah tersebut diteliti dengan menggunakan metode geoteknik yaitu CPT (Cone Penetration Test) dan SPT (Standar Penetration Test).

\section{Metode Penelitian}

Metode penelitian yang dilakukan yaitu investigasi geoteknik bawah permukaan yang terdiri dari pengeboran dan sondir. Namun data yang digunakan merupakan data sekunder hasil pengambilan tim peneliti geoteknik LIPI Bandung. Untuk mengidentifikasi ada tidaknya potensi likuifaksi menggunakan data bor (SPT) dan data sondir (CPT) merupakan salah satu cara untuk mengetahui ketahanan/kekuatan lapisan tanah terhadap potensi likuifaksi. Penentuan potensi likuifaksi yaitu berdasarkan besarnya data kegempaan yaitu magnitude gempa, percepatan maksimum tanah, jarak sumber gempa dengan daerah penelitian, dan berdasarkan data SPT dan CPT. Dari data SPT dan CPT akan didapatkan parameter kekuatan tanah menahan likuifaksi akibat 
gempa (CRR), tegangan geser tanah akibat gempa (CSR) dan factor keamanan atau safety factor. Safety factor yang digunakan dalam penelitian ini menggunakan batasan sebesar FS>1 menunjukan lapisan tanah tidak berpotensi terjadi likuifaksi sedangkan nilai $\mathrm{FS}<1$ menunjukan lapisan tanah berpotensi likuifaksi. Prosedur penelitian yang dilakukan dalam analisis potensi likuifaksi terlihat pada gambar 8 . 


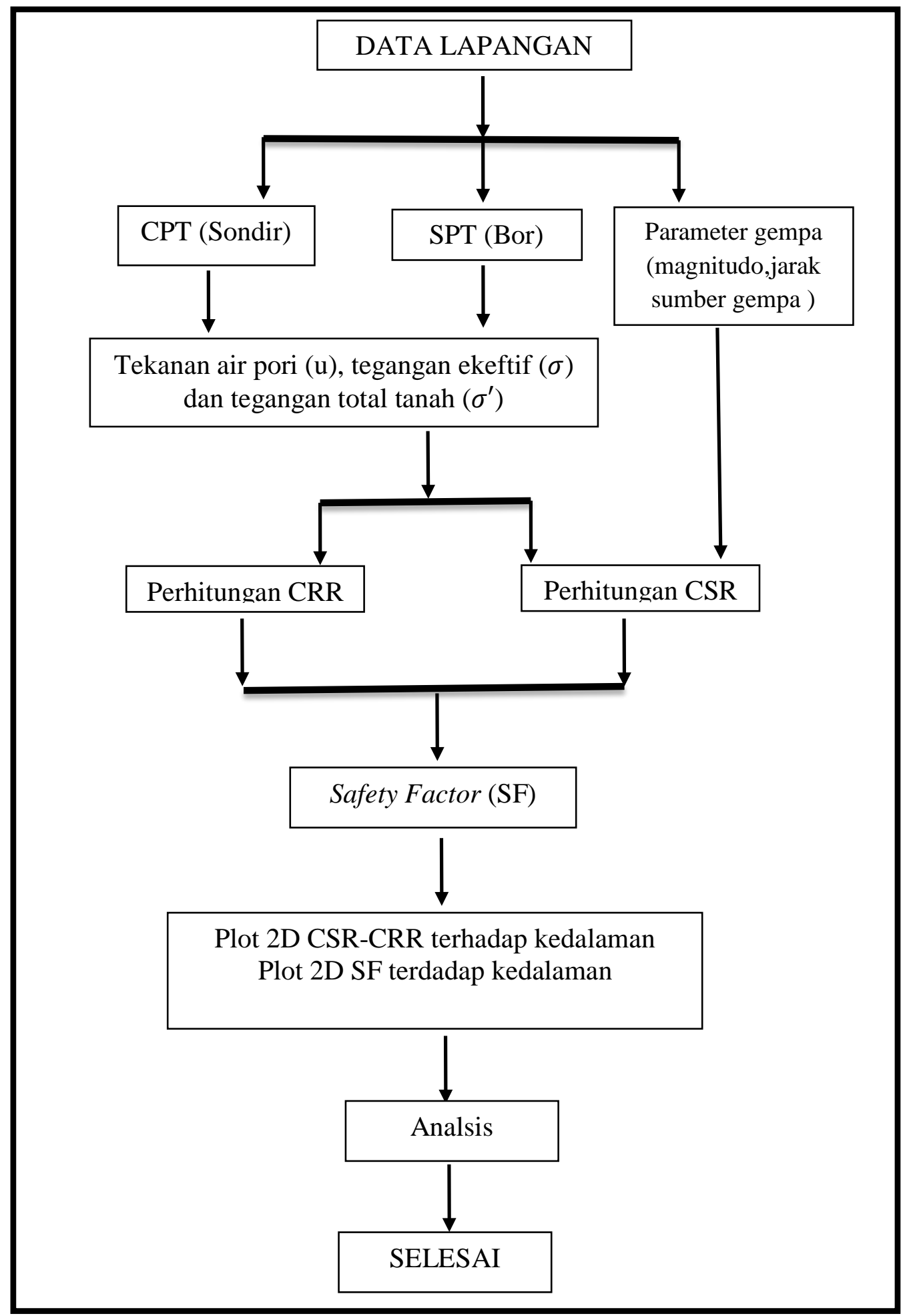

Gambar 8. Diagram Alur Penelitian.

\section{Hasil Dan Pembahasan}

Daerah Bantul memiliki jenis tanah berbutir halus dan berbutir kasar yang biasanya berupa tanah pasir, lanau, lempung, campuran pasir-lanau dan lempung-lanau. yang dibuktikan 
berdasarkan hasil pengolahan data CPT dan SPT. Gambar 9. 10, 11, 12 dan 13 merupakan karakteristik ukuran butiran tanah yang secara berturut-turut di daerah Sawahan, Pulokadang, Tilaman, Soronagan dan Gunungan berdasarkan data CPT.

Sedangkan berdasarkan data SPT dapat dilihat dari nilai berat isi tanah yang terdapat di tiap daerah penelitian. Jenis tanah lanau-pasir memiliki nilai berat isi pada rentang 18-19 kN/m, tanah lanau-lempung memiliki nilai berat isi $16-17 \mathrm{kN} / \mathrm{m}$, tanah lempung sebesar $17 \mathrm{kN} / \mathrm{m}$ dan tanah breksi sebesar $20 \mathrm{kN} / \mathrm{m}$.

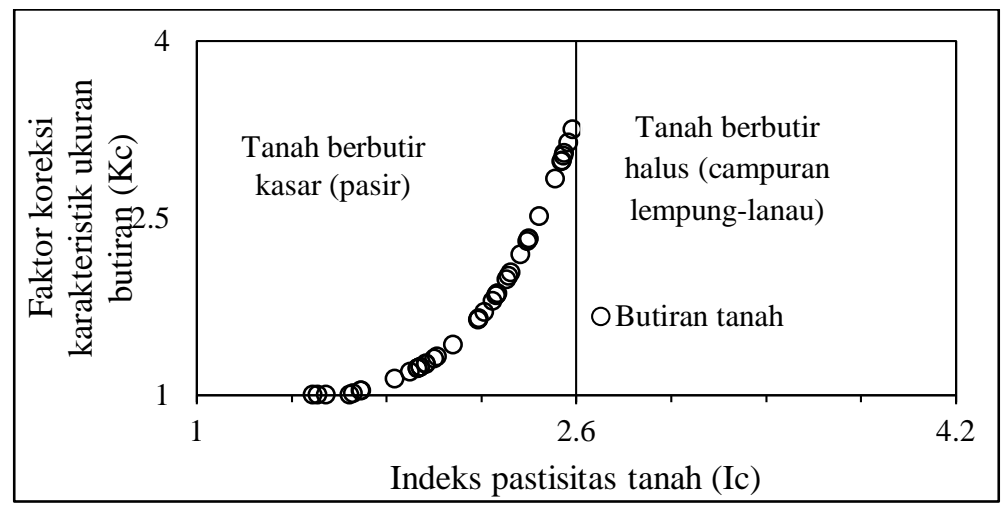

Gambar 9 Karakteristik ukuran butiran tanah daerah Sawahan

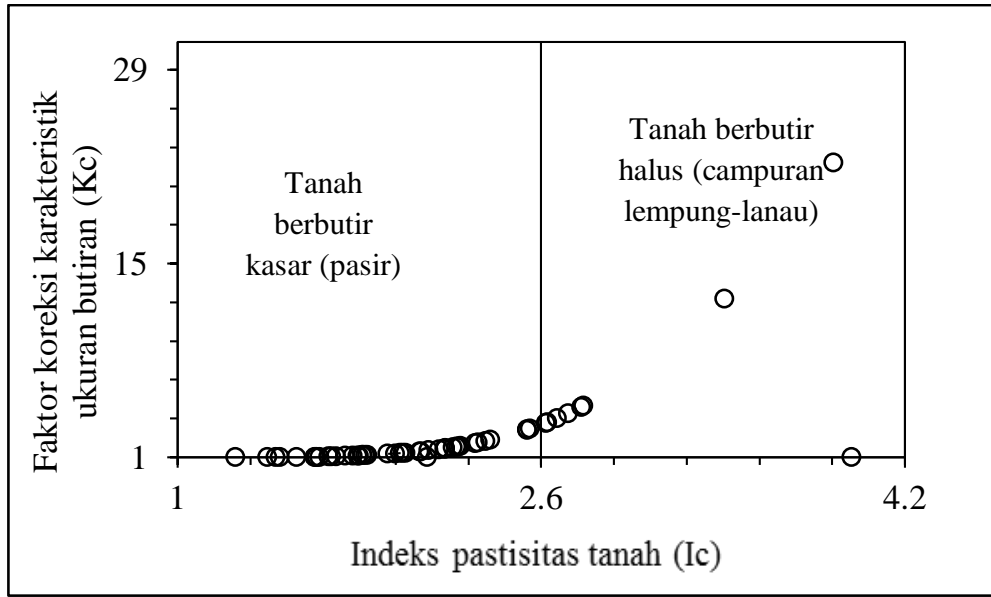

Gambar 10 Karakteristik ukuran butiran tanah daerah Pulokadang 


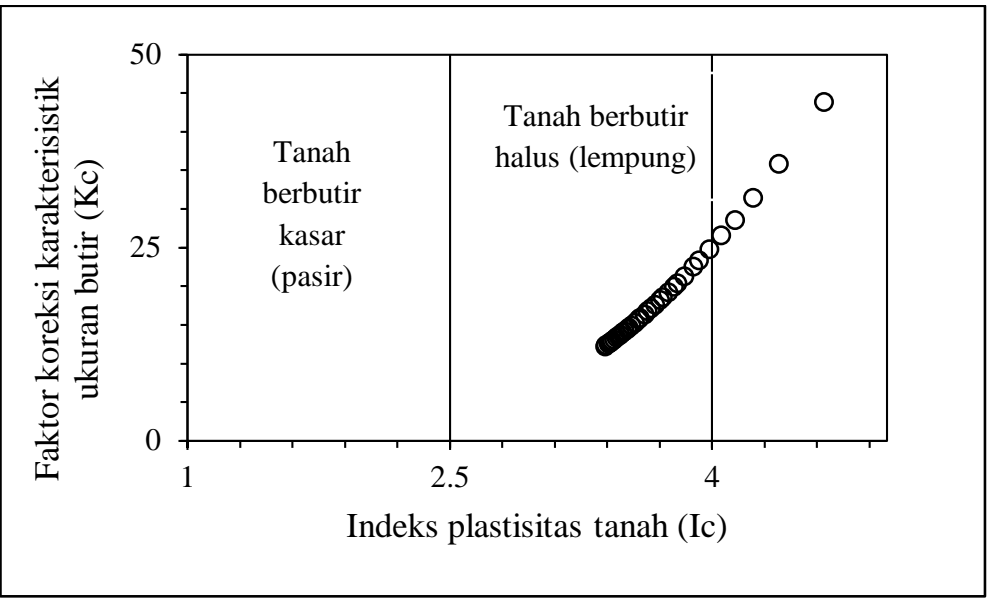

Gambar 11 Karakteristik ukuran butiran tanah daerah Tilaman

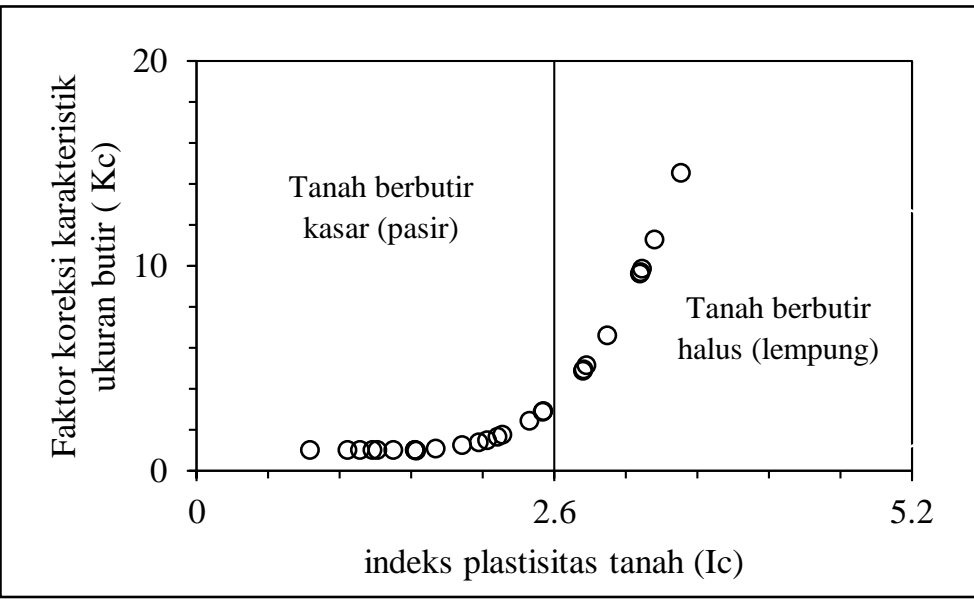

Gambar 12 Karakteristik ukuran butiran tanah daerah Soronagan

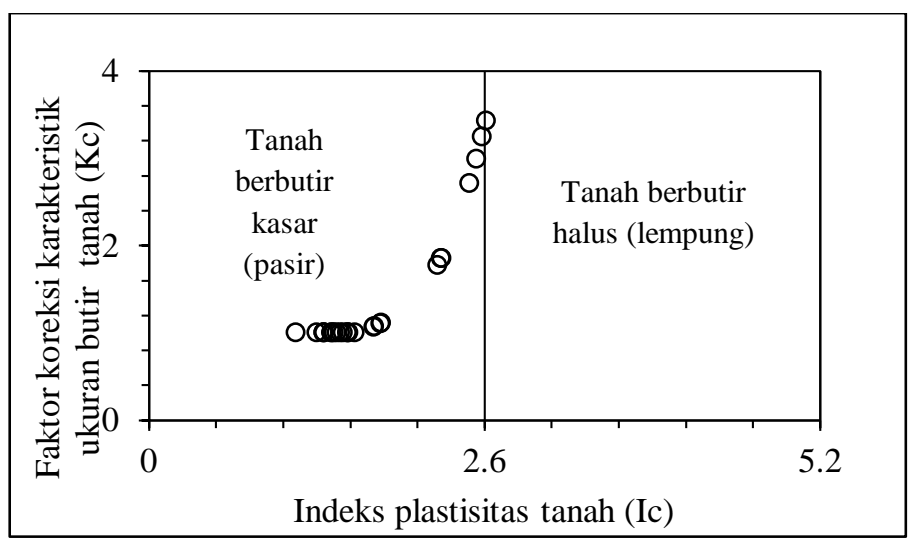

Gambar 13 Karakteristik ukuran butiran tanah daerah Gunungan

Berdasarkan nilai karakteristik ukuran butiran tanah berada pada nilai indeks plastis Ic $\geq 2.6$, maka tanah 
didominasi oleh butiran halus biasanya berupa tanah lempung atau tanah tanah lanau. Sedangkan jika bernilai Ic $\leq 2.6$ tanah didominasi oleh butiran kasar yang merupakan tanah pasir. Dari kelima gambar diatas, hampir semua daerah yang diteliti didominasi oleh tanah berbutir kasar. Daerah Tilaman didominasi oleh jenis tanah campuran lempung dan lanau.

Adapun untuk mementukan jenis tanah yang diusulkan oleh

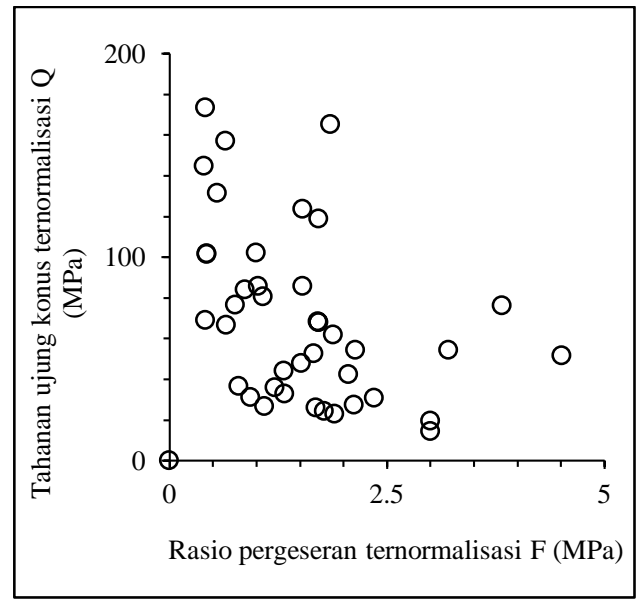

Gambar 14 Tipe tanah daerah

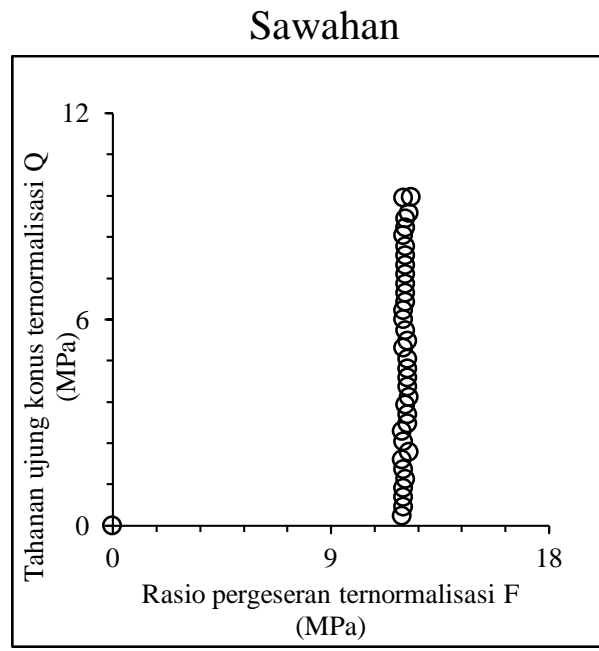

Gambar 16 Tipe tanah daerah Tilaman
Robertson (1990) yang dapat dilihat pada gambar 3.4. Berdasarkan data CPT, di daerah Sawahan, Pulokadang, Soronagan dan Gunungan rata-rata didominasi oleh jenis tanah campuran pasir lanau dan campuran pasir lempung. Seperti yang terlihat pada Gambar 14, 15, 16, 17 dan Gambar 18. Sedangkan daerah Tilaman sebagian besar didominasi oleh jenis tanah (campuran tanah lempunglanau).

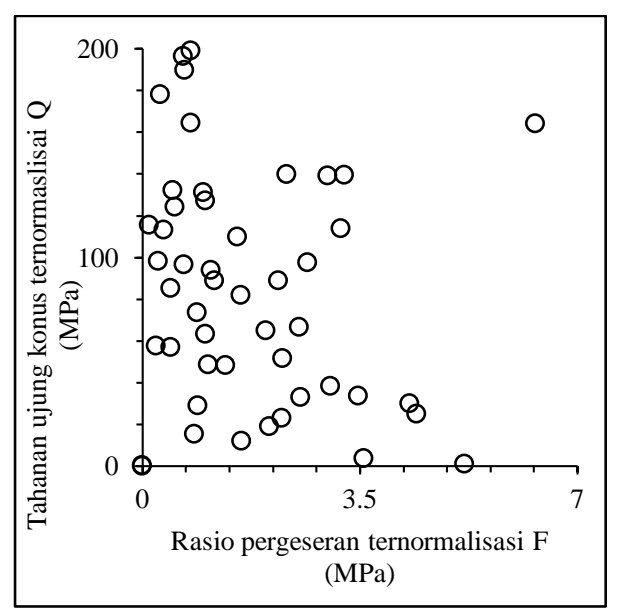

Gambar 15 Tipe tanah daerah

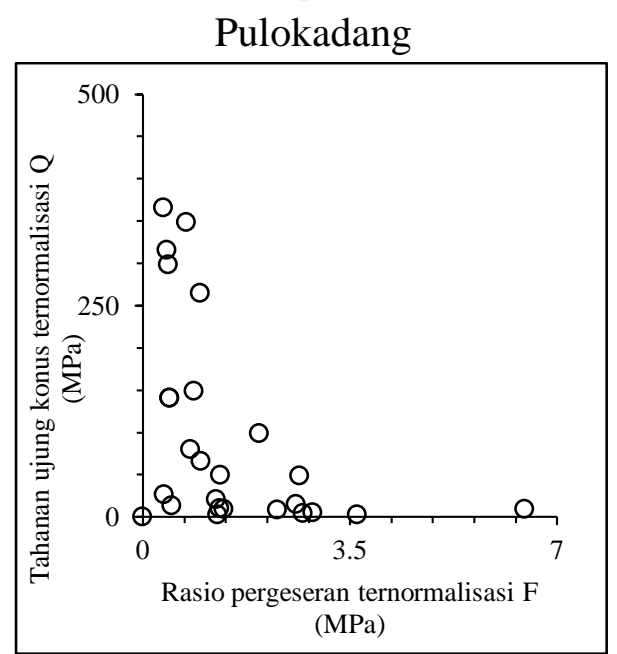

Gambar 17 Tipe tanah daerah Soronagan 


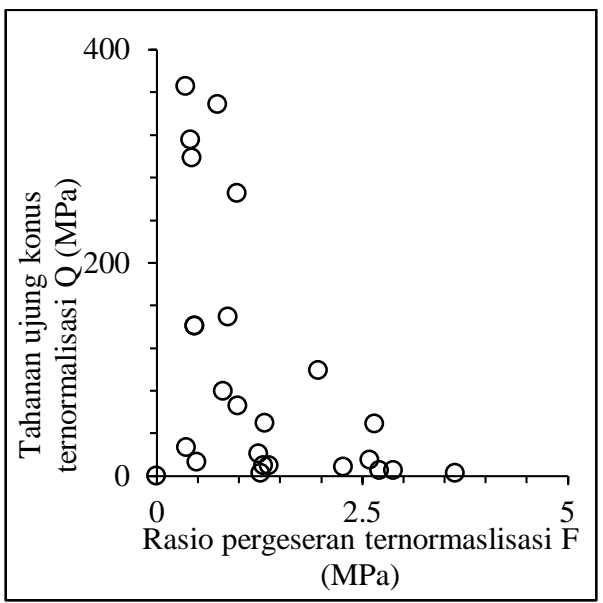

Gambar 18 Tipe tanah daerah Gunungan

Hasil pengolahan data SPT dan CPT pada lima daerah yang berbeda diantaranya Sawahan, Pulokadang, Tilaman, Soronagan dan Gunungan kabupaten Bantul, terdapat beberapa kedalaman tanah dari kelima daerah tersebut yang memiliki potensi terjadinya likuifaksi yaitu pada kedalaman 0.2-6 m

Gambar 19 menurut Gutenberg Richter dan Gambar 20 menurut Donovan, yang menunjukan hubungan antara cepat rambat gelombang gempa terhadap jarak.

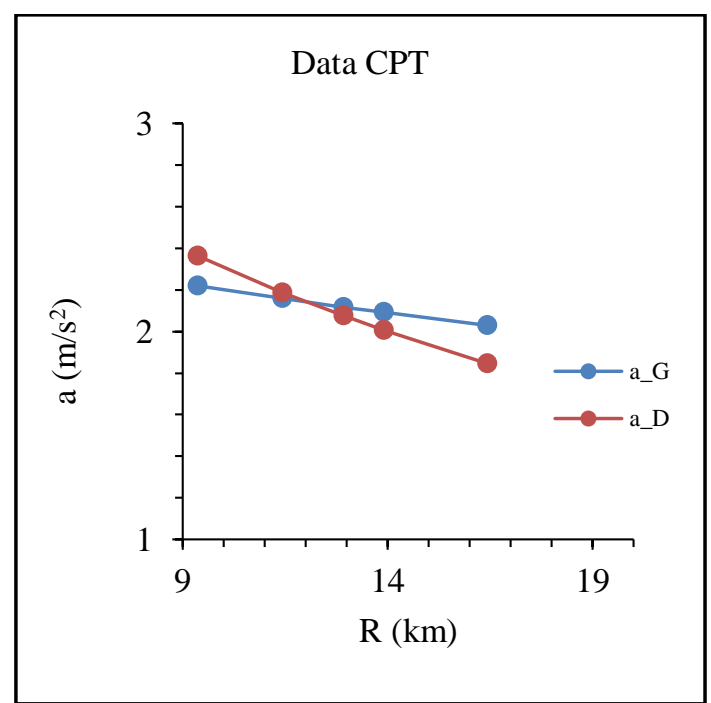

Gambar 19 Hubungan Percepatan Maksimum Tanah Akibat Gempa Bumi Dengan Jarak Daerah Penelitian berdasarkan data CPT 


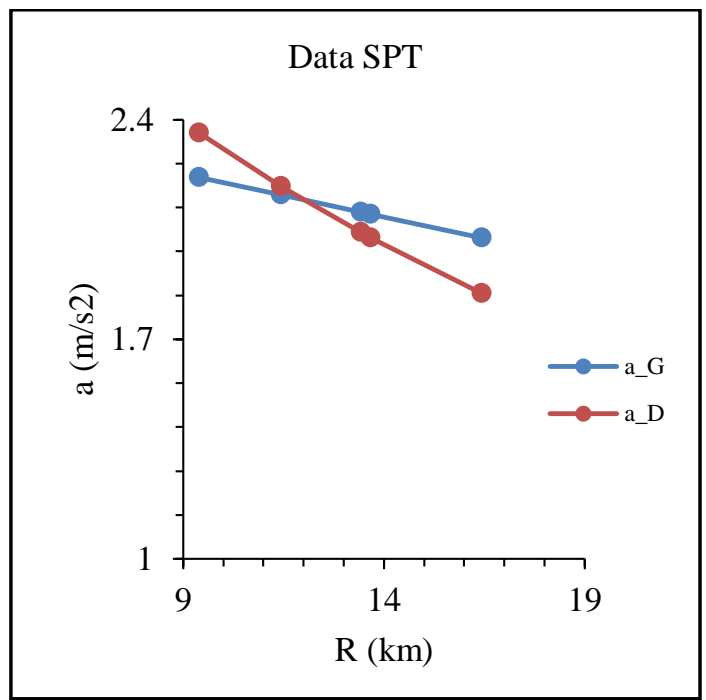

Gambar 20 Hubungan Percepatan Maksimum Tanah Akibat Gempa Bumi Dengan Jarak Daerah Penelitian berdasarkan data CPT

Dari kedua gambar tersebut menunjukan hubungan berbanding terbalik antara jarak sumber gempa dengan percepatan maksimum tanah akibat gempa bumi. Semakin jauh jarak sumber gempa dari daerah penelitian, maka akan semakin kecil nilai percepatan gempa yang sampai pada daerah penelitian tersebut. Hal ini dapat menyebabkan semakin kecil pula potensi likuifaksi di daerah tersebut. Percepatan gempa bumi menyebabkan berubahnya nilai tekanan air pori. Yang akhirnya menyebabkan terjadinya likuifaksi. Terutama terjadi pada jenis tanah pasir lanauan, karena tanah ini tidak mampu meredam energi yang dilepaskan oleh pusat gempa. Hal ini dibuktikan dengan analisis potensi likuifaksi berdasarkan data SPT dan CPT di lima daerah penelitian yaitu sebagai berikut:

\section{Sawahan}

Di daerah Sawahan memiliki daerah yang berpotensi likuifaksi yaitu berada pada kedalaman 1-3 m dan 7 m. Berdasarkan data CPT di daerah
Sawahan yang berpotensi likuifaksi yaitu pada kedalaman 0.2-2.4 m, 3.4 $\mathrm{m}$, dan 7.6- $8.2 \mathrm{~m}$. Sedangkan berdasarkan data SPT berada pada kedalaman 1.5-6 m, 9 m, dan 12-13.5 $\mathrm{m}$. Gambar 22 menunjukan potensi likuifaksi pada kedalaman yang sama berdasarkan nilai safety factor dari data SPT dan CPT yang bernilai $<1$. Sedangkan Gambar 21 menunjukan adanya potensi likuifaksi pada kedalaman yang sama berdasarkan nilai CSR dan CRR yang ditunjukan dengan nilai CSR lebih besar daripada nilai CRR. Lapisan tanah yang berpotensi likuifaksi berupa jenis tanah pasir lanauan. Sedangkan yang tidak berpotensi likuifaksi berupa lapisan tanah lempung lanauan.

Perbedaan kedalaman yang berpotensi likuifaksi dari data SPT dan CPT disebabkan pengambilan data yang berbeda. Data CPT pengambilan antara kedalaman lebih rapat namun memiliki kekurangan ketika tanah yang ditembus oleh konus berupa tanah kasar, sedangkan data SPT jarak antar kedalaman yang ditempuh 
lebih renggang dan ada gangguan keadaan tanah karena proses pengeboran.

\section{Pulokadang}

Berdasarkan data SPT di daerah Pulokadang yang memiliki potensi likuifaksi yaitu pada kedalaman $1.5 \mathrm{~m}$ dan $4.5 \mathrm{~m}$. Sedangkan berdasarkan data CPT berada pada kedalaman 0.4 - 2.4 m, 4.2 - 4.8 m, 5.2 dan 5.6 m. Gambar 24 menunjukan potensi likuifaksi pada kedalaman yang sama berdasarkan nilai safety factor dari data SPT dan CPT yang bernilai $<1$. Sedangkan Gambar 23 menunjukan adanya potensi likuifaksi pada kedalaman yang sama berdasarkan nilai CSR dan CRR yaitu pada kedalaman $1.5-4.5 \mathrm{~m}$. yang ditandai dengan lebih besarnya nilai tegangan geser akibat gempa bumi (CSR) daripada nilai kekuatan tanah untuk menahan likuifaksi (CRR). Tanah memiliki potensi likuifaksi jika nilai CSR lebih besar daripada nilai CRR.

\section{Tilaman}

Pada gambar 26 tersebut terlihat bahwa pada kedalaman 0.2 - $3.4 \mathrm{~m}$ berdasarkan data CPT yang berpotensi likuifaksi ketika nilai safety factor $<1$. Sedangkan berdasarkan data SPT yang berpotensi likuifaksi berada pada kedalaman 1.5 $\mathrm{m}, 4.5 \mathrm{~m}$ dan $7.5 \mathrm{~m}$. Berdasarkan kedua data tersebut ternyata memiliki potensi likuifaksi pada kedalaman yang sama. Namun ada juga perbedaan kedalaman yang memiliki potensi likuifaksi. Hal ini terjadi karena pengambilan data CPT spasi tiap kedalaman lebih kecil daripada data SPT. Maka berdasarkan data CPT akan lebih spesifik terhadap proses analisis tiap kedalaman yang berpotensi likuifaksi. Begitupun berdasarkan Gambar 25 yang menunjukan hubungan nilai CSRCRR terhadap kedalaman memiliki potensi likuifaksi pada kedalaman yang sama dan yang berbeda berdasarkan data SPT dan CPT.

\section{Soronagan}

Gambar 27 dan 28 menunjukan adanya kesamaan kedalaman yang berpotensi likuifaksi di daerah Soronagan diantaranya pada kedalaman $0.2-2.2 \mathrm{~m}, 2.6-2.8 \mathrm{~m}$ dan $3.6 \mathrm{~m}$ berdasarkan data CPT dan pada kedalaman $1.5-3 \mathrm{~m}, 7.5 \mathrm{~m}, 10.5 \mathrm{~m}$, dan $18 \mathrm{~m}$ berdasarkan data SPT. Gambar 29 menunjukan faktor keamanan likuifaksi ketika nilai safety factor $<1$, sedangkan Gambar 28 menunjukan hubungan antara nilai CSR-CRR terhadap kedalaman, dengan nilai CSR lebih besar daripada nilai CRR

\section{Gunungan}

Di daerah Gunungan yang berpotensi likuifaksi berada pada kedalaman 0.2 - $1.4 \mathrm{~m}$ berdasarkan data CPT, sedangkan berdasarkan data SPT berada pada kedalaman $1.05 \mathrm{~m}$ dan $7.5 \mathrm{~m}$ yang dapat dilihat pada gambar 29 dan gambar 30. Pada kedua Gambar tersebut menunjukan adanya kesamaan kedalaman yang berpotensi likuifaksi.

Dari kelima daerah penelitian, lapisan tanah yang berpotensi likuifaksi berupa tanah jenis pasir lanauan, sedangkan daerah yang tidak berpotensi terjadinya likuifaksi berupa jenis tanah campuran lempung lanau. Penampang bawah permukaan menunjukan perbedaan jenis lapisan tanah diantaranya jenis tanah pasir, lanau, lempung, campuran pasir lanau dan campuran lanau-lempung. Hal ini menunjukan telah terjadinya proses 
sedimentasi yang berulang di daerah

penelitian.
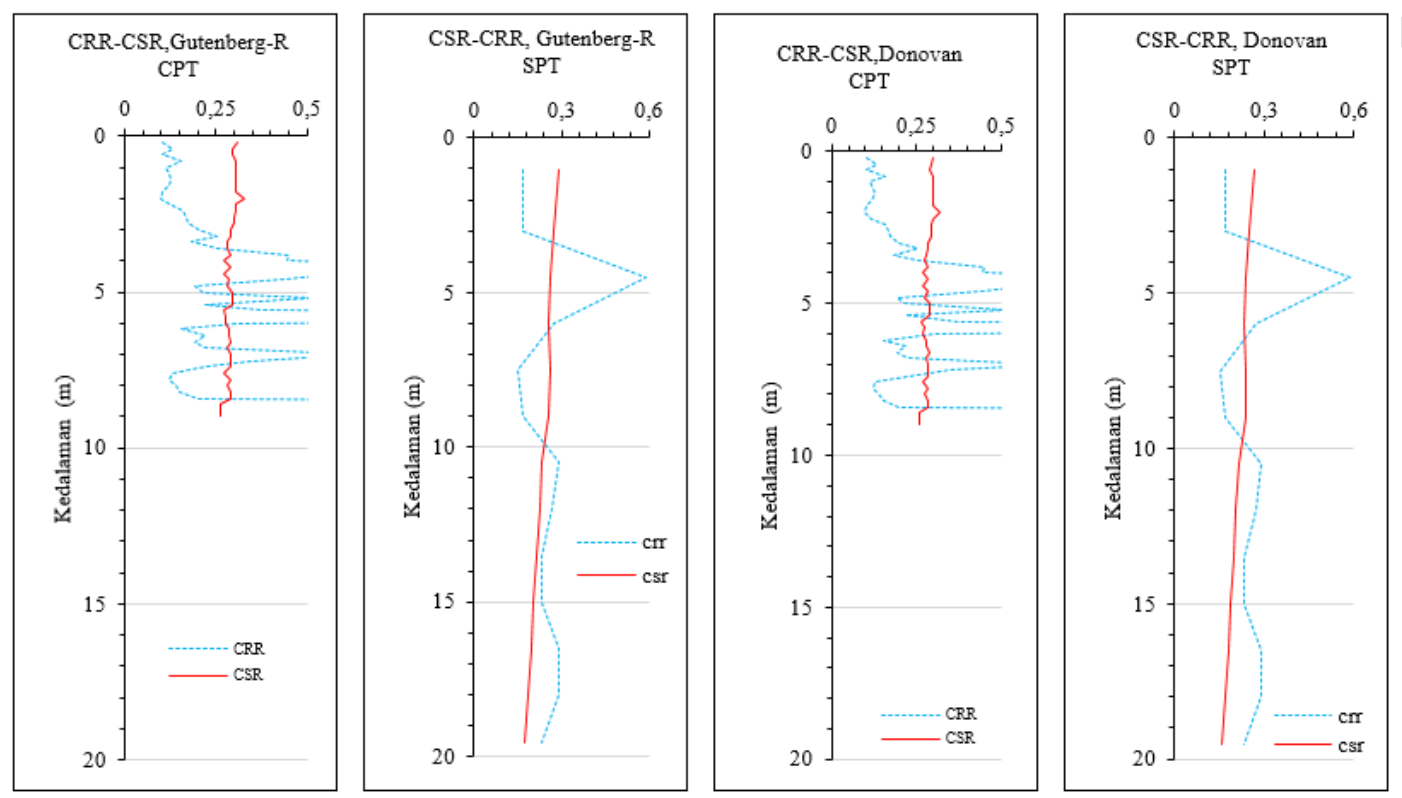

Gambar 21 Hubungan CSR-CRR dengan percepatan maksimum tanah menurut Gutenberg Richter dan Donovan berdasarkan data SPT dan CPT di daerah Sawahan
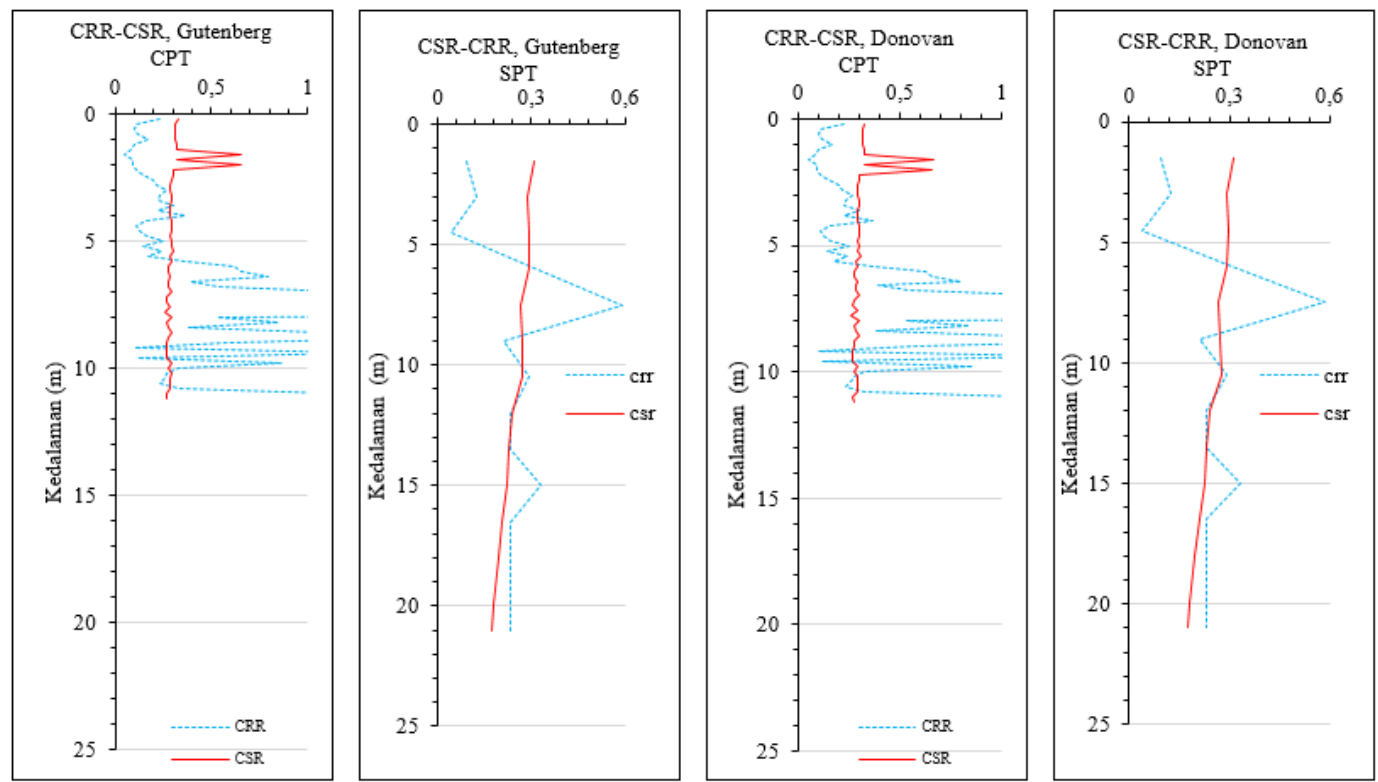

Gambar 23 Hubungan CSR-CRR dengan percepatan maksimum tanah menurut Gutenberg Richter dan Donovan berdasarkan data SPT dan CPT di daerah Pulokadang 

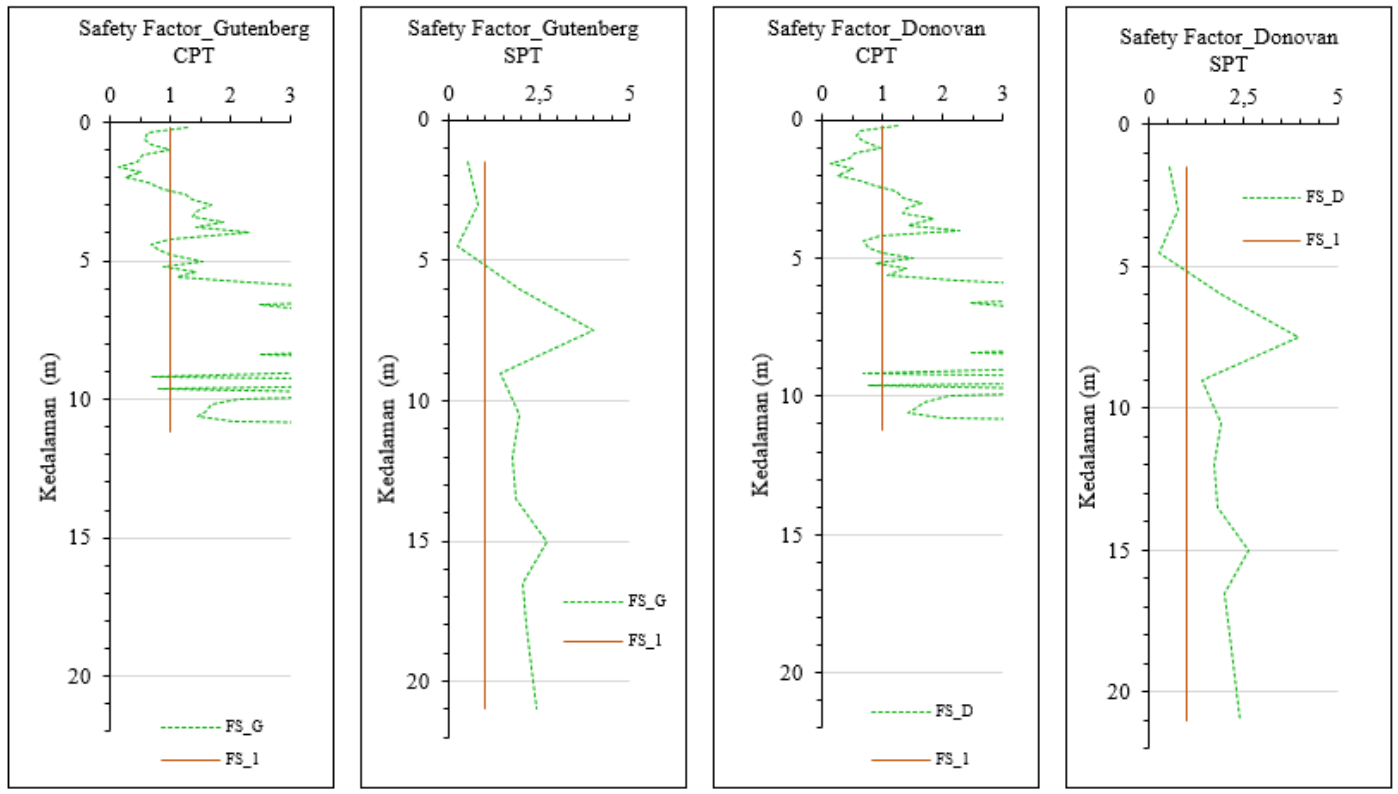

Gambar 24 Faktor Keamanan Likuifaksi di daerah Pulokadang berdasarkan data SPT dan CPT
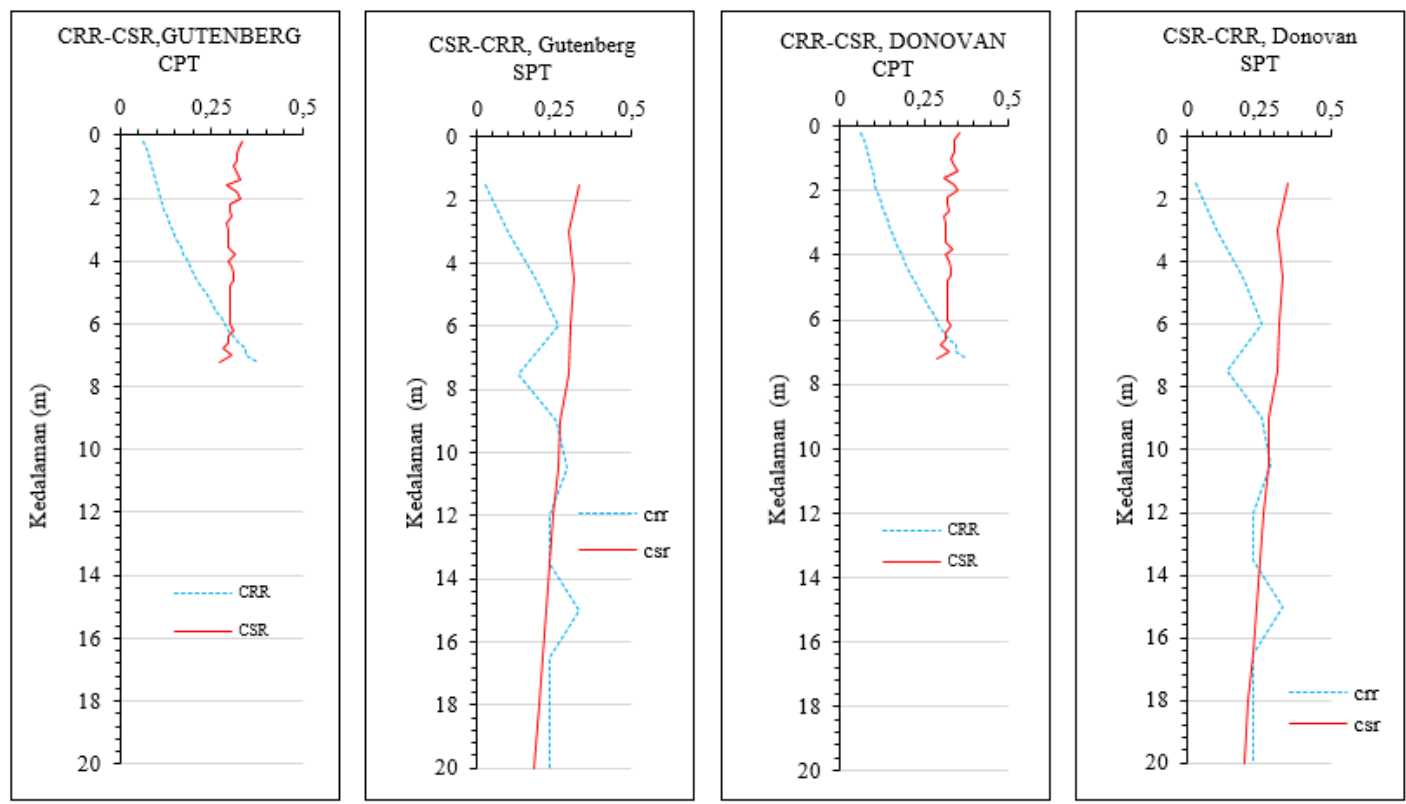

Gambar 25 Hubungan CSR-CRR dengan percepatan maksimum tanah menurut Gutenberg Richter dan Donovan berdasarkan data SPT dan CPT di daerah Tilaman 

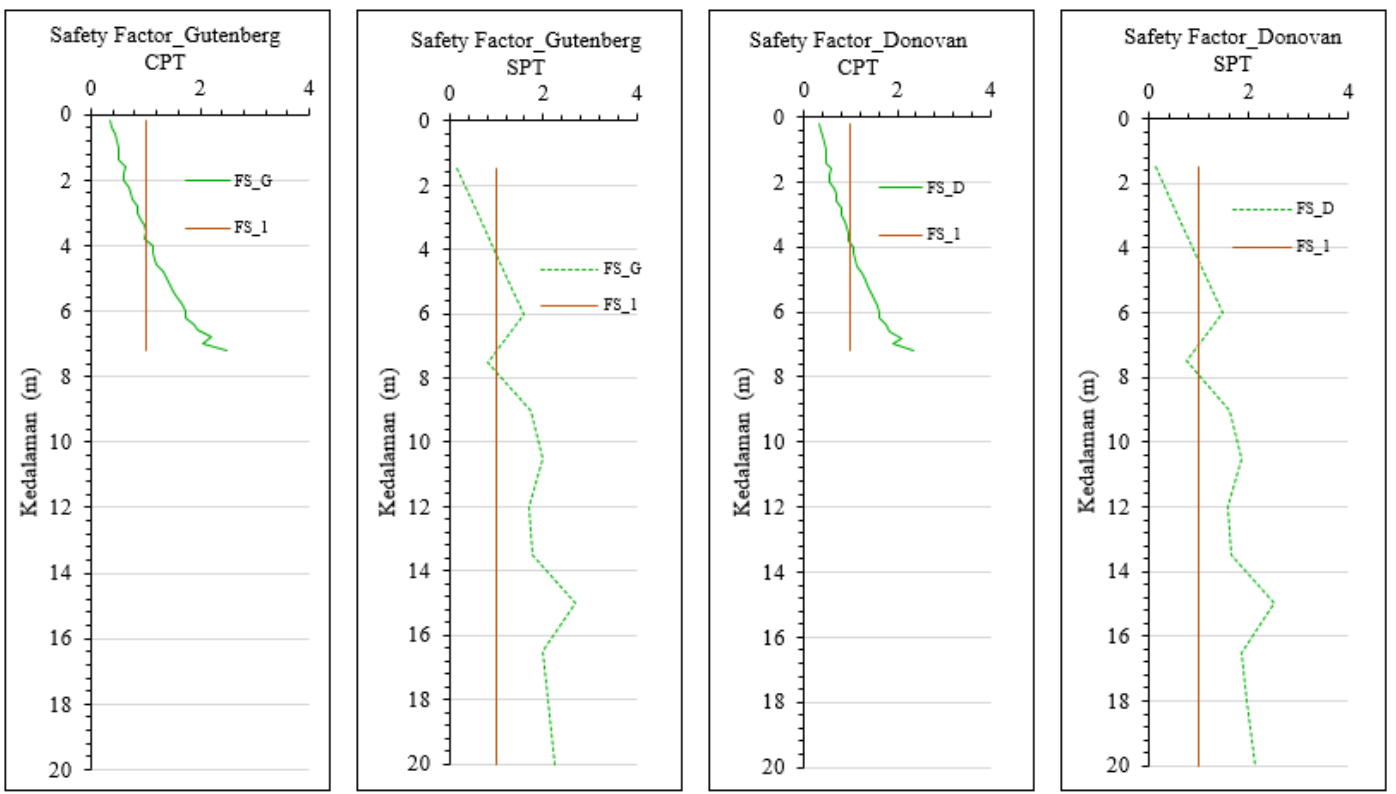

Gambar 26 Gambar 26 Faktor Keamanan Likuifaksi di daerah Tilaman berdasarkan data SPT dan CPT
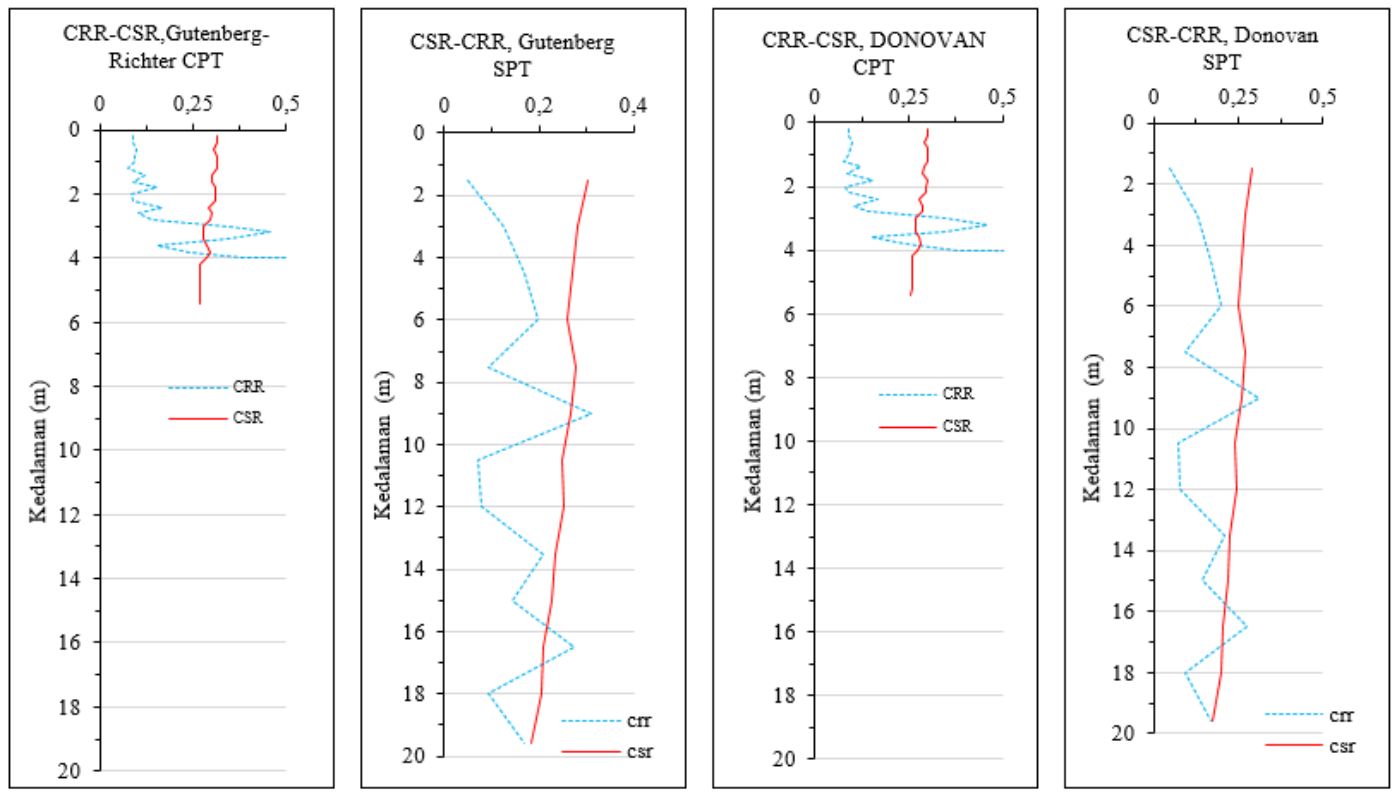

Gambar 27 Hubungan CSR-CRR dengan percepatan maksimum tanah menurut Gutenberg Richter dan Donovan berdasarkan data SPT dan CPT di daerah Soronagan 

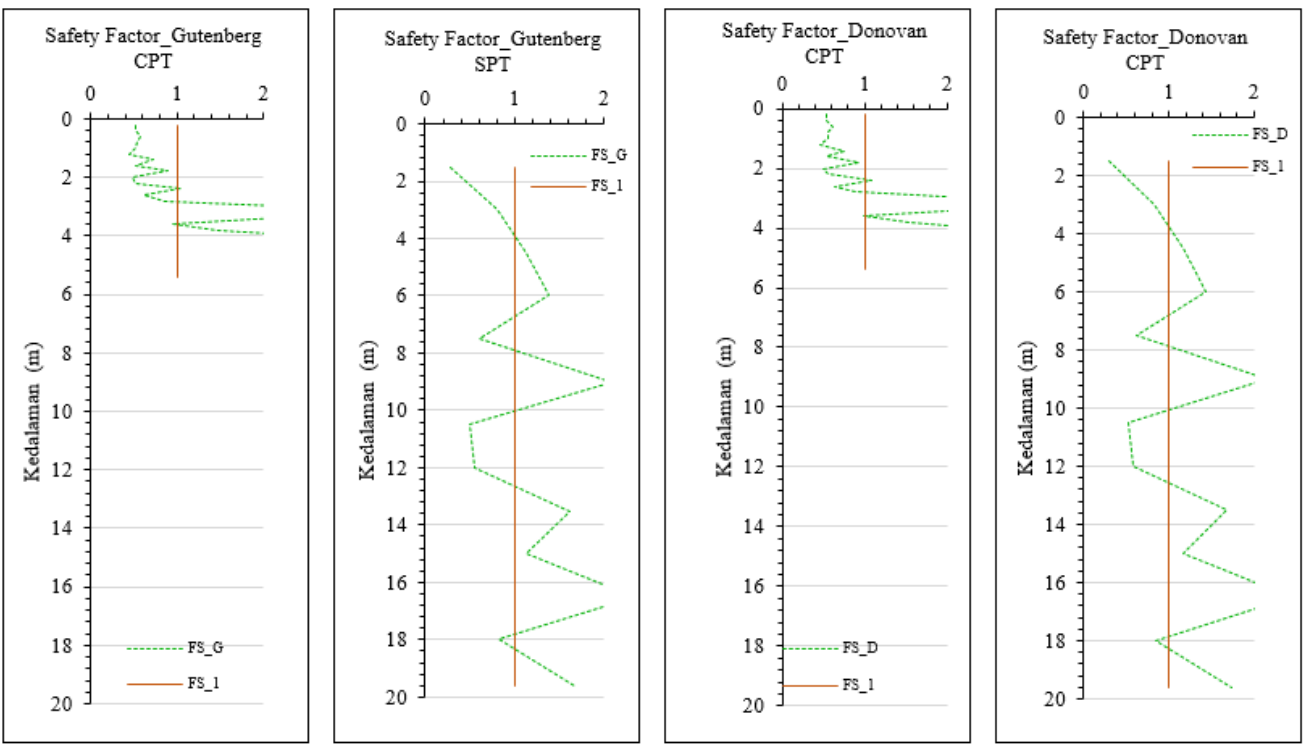

Gambar 28 Faktor Keamanan Likuifaksi di daerah Soronagan berdasarkan data SPT dan CPT
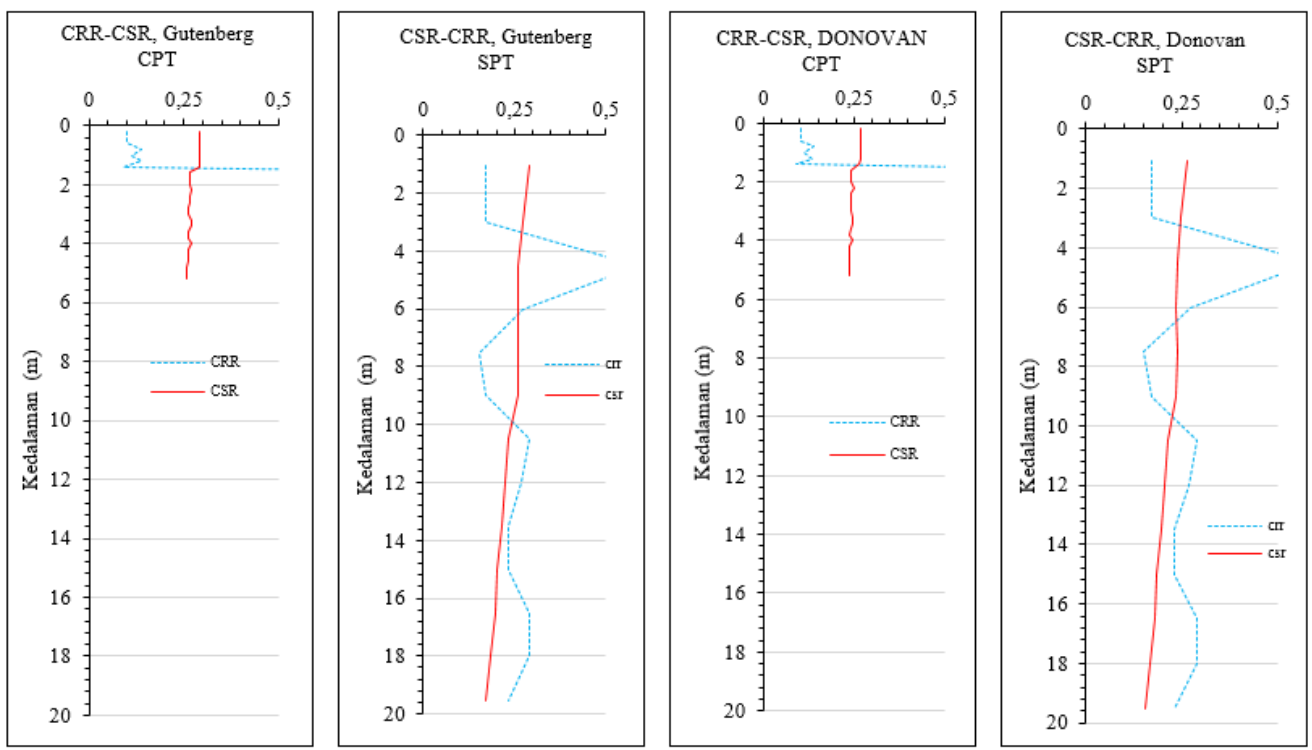

Gambar 29 Hubungan CSR-CRR dengan percepatan maksimum tanah menurut Gutenberg Richter dan Donovan berdasarkan data SPT dan CPT di daerah Gunungan 

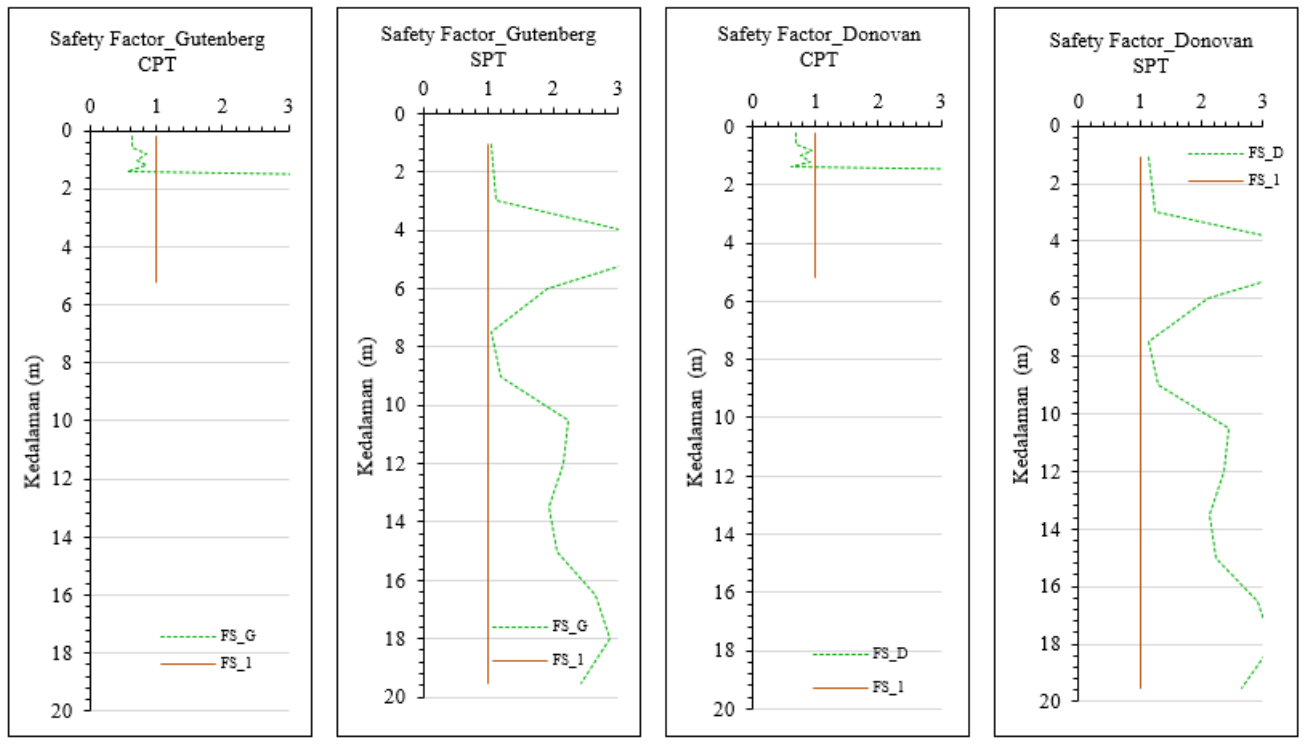

Gambar 30 Faktor Keamanan Likuifaksi di daerah Gunungan berdasarkan data SPT dan CPT

Ketika terjadi gempa, air yang berada pada pori-pori tanah tidak sempat keluar sehingga terjadi peningkatan air pori. Sedangkan butir-butir tanah akan mengalami pemadatan. Peningkatan air pori akan menyebabkan mengecilnya gaya tarik antar butir-butir tanah sehingga kekuatan tanah akan menurun. Selain itu, peningkatan air pori akan menyebabkan terjadinya peningkatan tegangan total tanah. Jika nilai tekanan air pori sebanding dengan nilai tegangan total tanah, maka tanah akan kehilangan tegangan efektif yang akan mengakibatkan tanah berperilaku sebagai benda cair (Fluid viscous) yang biasanya terjadi pada jenis tanah pasir. Hal ini terbukti berdasarkan perhitungan korelasi antara tekanan air pori terhadap tegangan total yang terjadi pada lapisan tanah akibat gempa bumi di lima daerah penelitian berdasarkan data SPT dan CPT dapat dilihat pada gambar 31-40. 


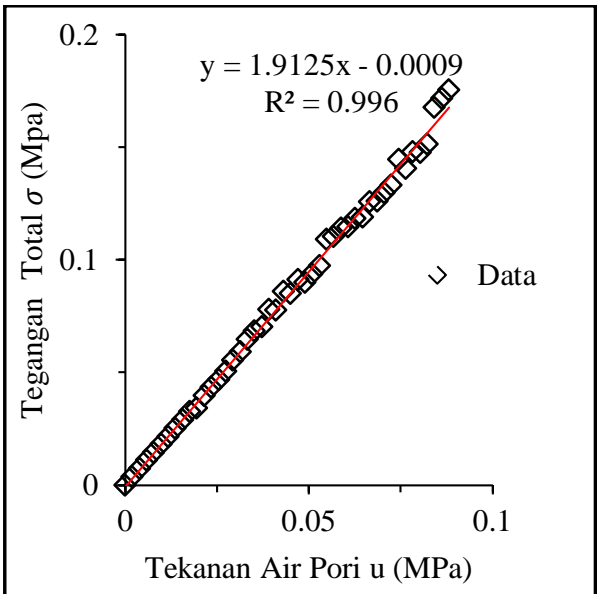

Gambar 31 korelasi tekanan air pori dan tegangan total daerah Sawahan berdasarkan data CPT

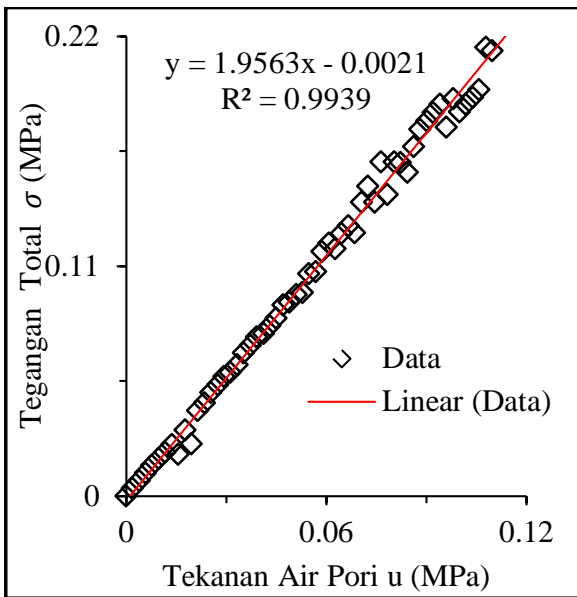

Gambar 33 Korelasi tekanan air pori dan tegangan total daerah Pulokadang berdasarkan data CPT

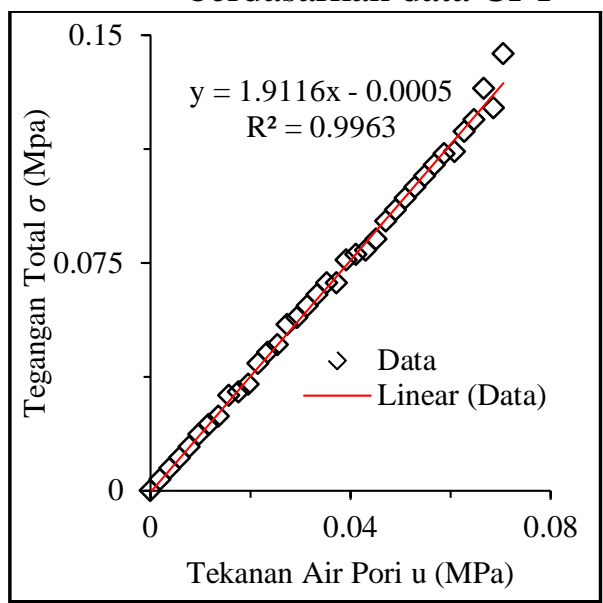

Gambar 35 Korelasi tekanan air pori dan tegangan total daerah Tilaman berdasarkan

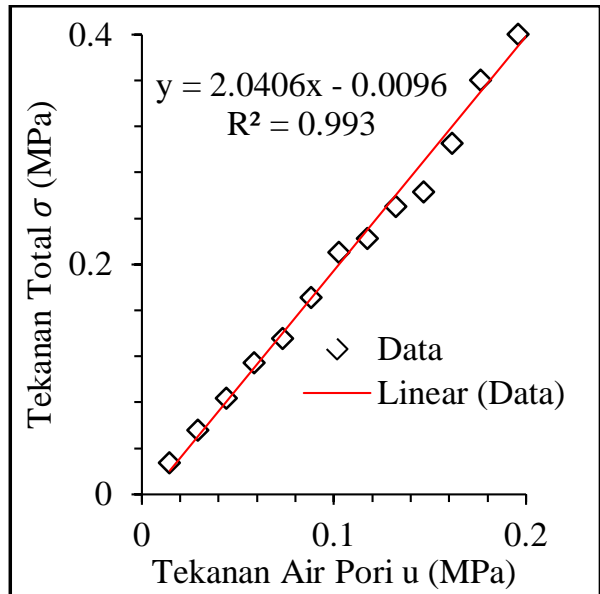

Gambar 32 korelasi tekanan air pori dan tegangan total daerah Sawahan berdasarkan data SPT

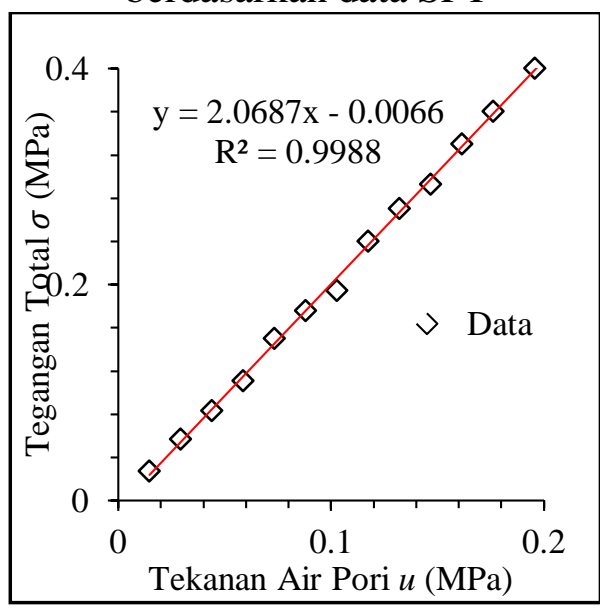

Gambar 34 Korelasi tekanan air pori dan tegangan total daerah Pulokadang berdasarkan data SPT

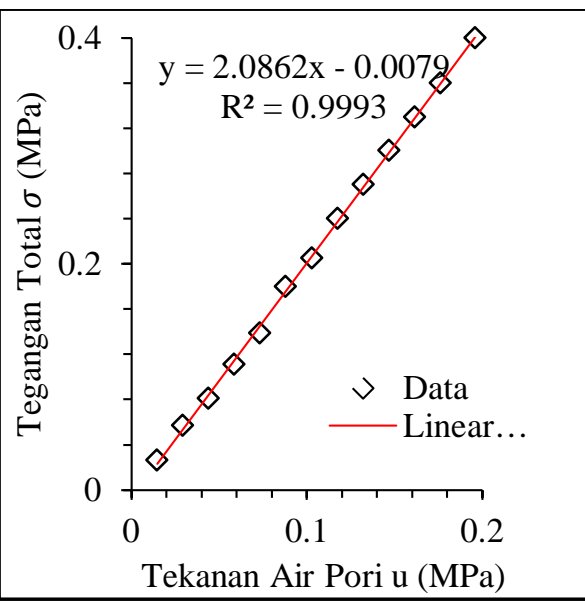

Gambar 36 Korelasi tekanan air pori dan tegangan total daerah Tilaman 


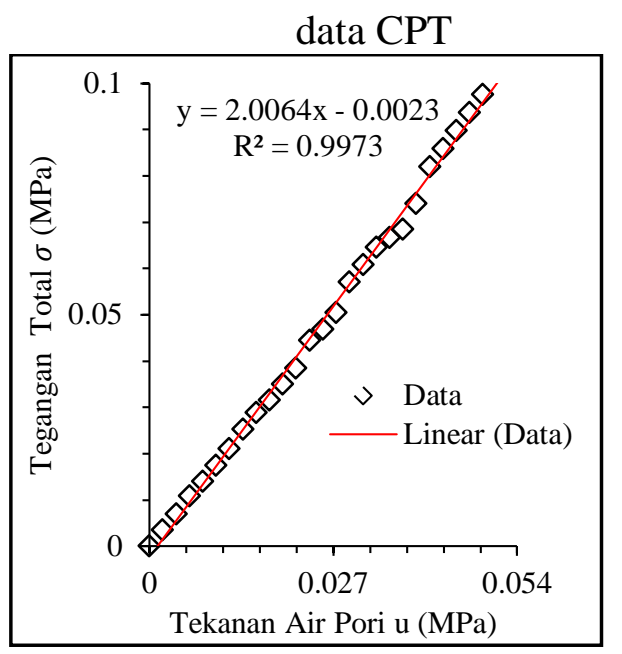

Gambar 37 Korelasi tekanan air pori dan tegangan total daerah Soronagan berdasarkan data CPT

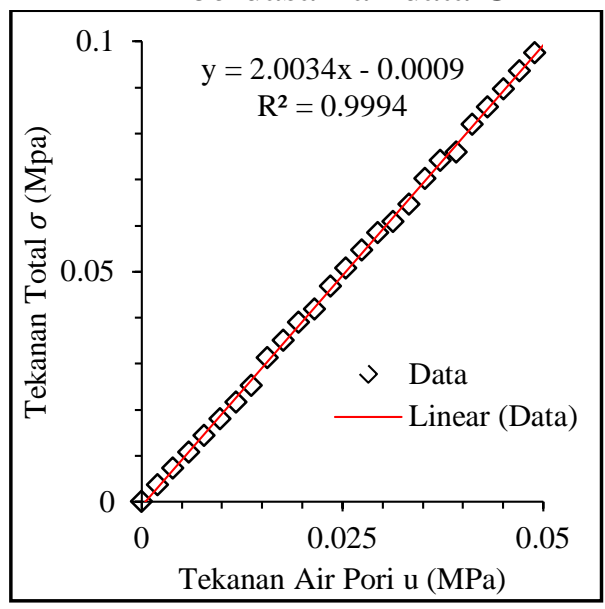

Gambar 39 Korelasi tekanan air pori dan tegangan total daerah Gunungan berdasarkan data CPT

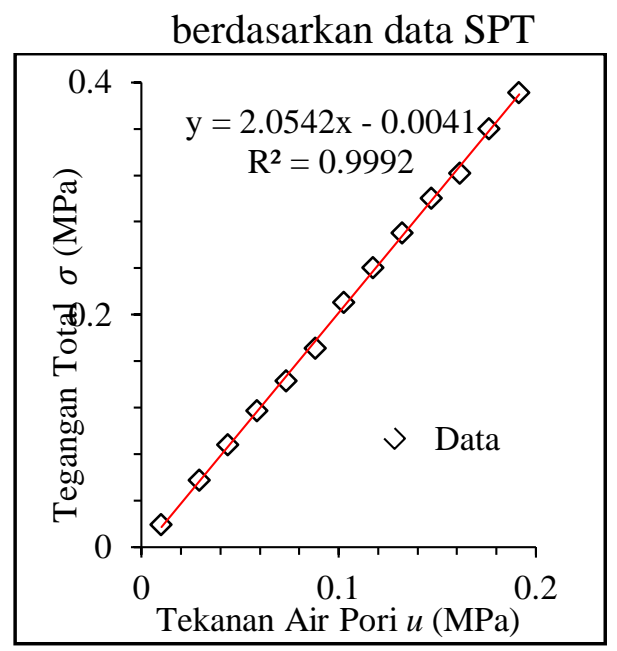

Gambar 38 Korelasi tekanan air pori dan tegangan total daerah Soronagan berdasarkan data SPT

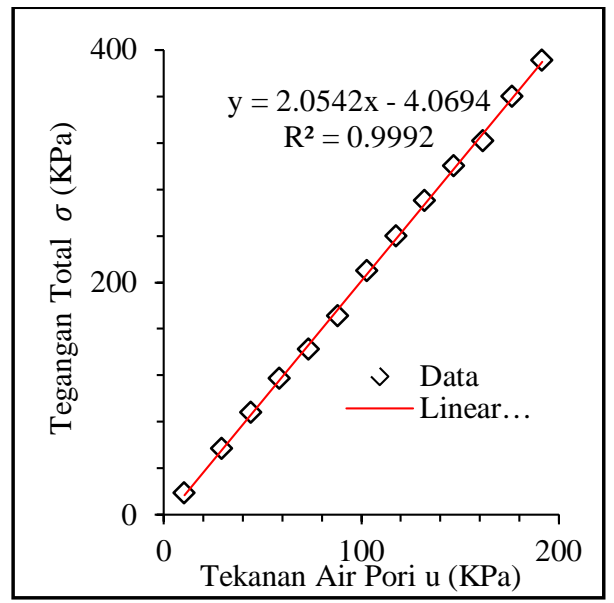

Gambar 40 Korelasi tekanan air pori dan tegangan total daerah Gunungan berdasarkan data SPT

\section{Simpulan}

Percepatan gempa menurut Gutenberg Richter berdasarkan data CPT dan SPT dari kelima daerah rata-rata bernilai $2.93 \mathrm{~m} / \mathrm{s} 2$ dan $2.44 \mathrm{~m} / \mathrm{s} 2$ sedangkan menurut Donovan bernilai $2.88 \mathrm{~m} / \mathrm{s} 2$ dan $2.37 \mathrm{~m} / \mathrm{s} 2$. Percepatan gempa menurut Gutenberg Richter lebih besar terhadap terjadinya potensi likuifaksi daripada menurut Donovan. Semakin besar gempa yang terjadi di suatu daerah, maka kemungkinan terjadi likuifaksi pun akan semakin besar.

Gempa bumi berpengaruh pada terjadi likuifaksi di lima daerah yang diteliti, diantaranya daerah Sawahan, Tilaman, Pulokadang, Soronagan dan Gunungan, semua daerah tersebut memiliki potensi terjadinya likuifaksi, diantaranya berada pada kedalaman $0.2-3 \mathrm{~m}, 3.6 \mathrm{~m}, 4 \mathrm{~m}, 7.6-7.8 \mathrm{~m}$ dan 
$8.2 \mathrm{~m}$. Daerah yang berpotensi likuifaksi didominasi oleh jenis tanah pasir lanauan dan lanau pasiran.

Dari data sondir dan data bor pada titik yang saling berdampingan menunjukan adanya kesamaan lapisan tanah yang memiliki potensi likuifaksi pada kelima daerah yang diteliti. Yang dapat dilihat dari nilai CSR berdasarkan data SPT dan CPT yaitu rata-rata bernilai 0.2. Namun berdasarkan nilai CRR dari kedua metode tersebut ada perbedaan nilai, hal ini terjadi karena pengambilan data CPT memiliki keterbatasan terhadap tanah pasir keras (pasir mengandung kerikil). Namun berdasarkan kedua metode tersebut, metode CPT lebih baik daripada metode SPT. Hal ini terjadi karena data CPT lebih rapat dibandingkan dengan data SPT.

\section{Referensi}

1. Boulanger, R.W. dan Idriss, I.M. (2014). CPT and SPT Based Liquefaction Triggering Procedure. California : University Of California

2. Craig, R.F. (2005). Craig Soil Mechanics. London \& New York: Taylor and Prancis Library

3. Daryono. (2010). "Aktivitas Gempa Bumi Tektonik di Yogyakarta Menjelang Erupsi Merapi”.

4. Edwiza,Daz. (2008). “Analisisi Terhadap Intensitasn dan Percepatan Tanah Maksimum Gempa Sumbar”. Jurnal Teknik. 29, (1), 73-79

5. Febi, Dwi, dkk. (2004). Analisis Potensi Soil Liquefaction Di
Daerah Pesisir Kota Pacitan Berdasarkan Data CPT. Institut Teknik Surabaya.

6. http://www.astronomynotes.com/ solarsys/s8c.htm

7. http://wapi.isu.edu/envgeo/EG5_ earthqks/eg_mod5.htm

8. Ihsan, Mohammad. (2008). Analisa Ketahanan Gempa. Jakarta: Fakultas Tekhnik Universitas Indonesia.

9. Ikhsan, Rifa. (2011). Analisis Potensi Likuifaksi Dari Data CPT Dan SPT Dengan Studi Kasus PLTU Ende Nusa Tenggara Timur. Skripsi Teknik Sipil : Universitas Indonesia.

10. Kramer, S.L. (1996). Geothecncal Eartquake Enginering. Englewood Cliffs: Prentice Hall.

11. Kramer S.L. (2008). Evaluation of Liquefaction Hazards in Washington State. Amerika: Office of Research and Library Service.

12. Maulana, Indra dkk. (2013). "Studi Perubahan Karakteristik Fisik, Mekanik Dan Dinamik Tanah Terhadap Siklus Pembasahan Dan Pengeringan Pada Tanah Permukaan Lereng Di Ngantang - Malang”. Jurnal Teknik Pomits. 7, (14), 1-8.

13. Misliniyati, Rena dkk. (2013). "Pemetaan Potensi Likuifaksi Wilayah Pesisir Berdasarkan Data Cone Penetratition Test di Kelurahan Lempuing, Kota 
Bengkulu”. Jurnal Inersia. 5, (2), 1-10.

14. Muntohar, Setyo A.(2009). Mokro-Zonasi Likuifaksi dan Penurunan Tanah Akibat Gempa Bumi. Penelitian Universitas Muhamadiyah Yogyakarta.

15. M. Das, Braja. (2007). Advanced Soil Mechanics. London \& New York: Taylor and Prancis Library.

16. Pantas, Saut. (2015). Percobaan Potensi Likuifaksi Pada Tanah Pasir Seragam Dengan Pemodelan Alat di Laboratorium. Skripsi:Universitas Andalas.

17. Robertson, dkk. (1998). Standard Penetration Test.

18. Seed H.B, and Idriss I.M. (1971). "Simplified Procedure for Evaluation Soil Liquefaction Potential". Journal of Soil Mechanics and Foundantion. 97, (9), 1249-1273.

19. Soebowo, dkk. (2009). "Potensi Likuifaksi Akibat Gempa Bumi Berdasarkan Data CPT dan SPT Di Daerah Patalan Bantul, Yogyakarta”. Junal Riset Geologi dan Pertambangan. 19, (2), 8597.

20. Sucipto, Y.A. (2015). Penggunaaan CPT Untuk Quality Control Tanah Pasir Reklamasi Terhadap Potensi Likuifaksi Berdasarkan Uji Sel Kalibrasi Dan Konsep Critical State. Tesis: tidak diterbitkan.

21. Syahbana, A.J, dkk. (2013). "Pemodelan 2D Perubahan
Tekanan Air Pori hubungannya dengan Likuifaksi: Studi Kasus Kabupaten Bantul, Daerah Istimewa Yogyakarta”. Jurnal Lingkungan dan Bencana Geologi. 4, (3), 163-177.

22. USGS. (2006). Earthquake Yogyakarta, May 27, 2006.

23. Wesley, Laurence D. (2012). Mekanika Tanah Untuk Tanah Endapan dan Residu. Yogyakarta: Andi.

24. Youd, T. Leslie. (1992). "Liquefaction Ground Failure and Consequent Damage During the 22 April 1991 Costa Rica Earthquake”, in Proceedings of the NSF/UCR U.S. Costa Rica Workshop on the Costa Rica Earthquake of 1990-1991: Effects on Soil and Structures. Oklanda, California: Earthquake Engineering Research Institute.

25. Youd. T.L. dan Idriss, I.M. (2001). “ Liquefaction Resistance of Soils: Summary Report from the 1996 NCEER and 1998 NCEER/NSF Workshops Evaluation of Liquefaction Resistance of soils”. Journal of Geotechnical and Geoenvironmental Engineering. 297-313.

26. Yuksel, Z.T,dkk. (2011).” Soil Liquefaction Induced 